\title{
Developing the Key Constructs of Career Literacy: A Delphi Study
}

\author{
Kesha S. Valentine, Michael F. Kosloski \\ Old Dominion University
}

\begin{abstract}
Career literacy is a concept that is often misunderstood, yet it is something that can be developed to enhance youth's potential for career readiness and career growth. This study sought to determine the knowledge and skills required for career literacy and to identify the optimal time to acquire these skills. A four-round Delphi study was designed and implemented to determine such skills and the ideal corresponding time of acquisition for each. The research indicated a final list of 50 skills and knowledge, all of which fall under the categories of functional, interactive, and critical skills a student needs to be able to read, understand, and make decisions on career-related information. These skills and knowledge can be used not only to inform stakeholders what to infuse into existing curricula, but also to identify the optimal time of introduction into a student's educational career.
\end{abstract}

Keywords: career literacy, career readiness, career growth, Delphi, career skills and knowledge

Disparities in educational opportunities exist as a factor of the resources available within schools and communities. In concentrated areas of low-income, students receive fewer rigorous academic assignments and, in general, their career trajectory is stifled based on their current educational situation (Leland et al., 2007). Equity is becoming a significant topic in the educational arena, especially regarding access of materials and opportunities. In an effort to level the playing field for students, the Virginia legislature mandated that students prepare college and career plans and receive curricular instruction addressing career investigations no later than the $8^{\text {th }}$ grade (College and Career Readiness, 2019). There is limited research that indicates students are currently assessed for their ability to read and understand career-related material or to analyze and make decisions based on their career and academic interests (Kulcsar et al., 2020). While career exploratory resources are widely available to students, there is limited research indicating that students are able to decipher the career information available through those resources.

Adding to the importance of this discussion is the timing and emphasis related to the development of students' career-related skills which traditionally happens during high school (Tang et al., 2008). In order to make the most informed decisions about what it will take to prepare students for evaluating their post-secondary opportunities, which could begin to erase inequities, it is important to analyze students' capacities to make informed decisions regarding

cc) (7) $\odot$ Creative Commons CC-BY-NC-ND: This article is distributed under the terms of the Creative Commons Attribution 4.0 License (http://creativecommons.org/licenses/by/4.0/) which allows others to download your works and share them with others as long as they credit you, but they can't change them in any way or use them commercially. 
their career preparation in a secondary school setting. To prepare a student to take advantage of the post-secondary preparation available through their school and community, students need the skills to be able to understand, interpret, evaluate, and make decisions related to career information.

Career literacy preparation involves a set of experiences that lead to the knowledge acquisition and skill development necessary to understand, interpret, and evaluate career-related information. This body of experiences can be broken down into three categorical representations: functional, interactive, and critical, with functional indicating the basic knowledge and skills required to read and understand career-related information. Interactive refers to the knowledge and skills necessary to interpret the career-related information being read. Critical knowledge and skills are those that facilitate a student's ability to evaluate and make decisions based on career-related information (Doustmohammadian et al., 2017; Lau \& Yuen, 2014; Vidgen \& Gallegos, 2014). At the pinnacle of career literacy, individuals will be able to make wellinformed decisions in preparation for their post-secondary life.

In contrast, career-readiness refers to "knowledge, skills, and attitudes needed to secure and retain adequately compensated employment" (ERIC, 2020, para. 1). The emphasis of career literacy is to prepare individuals to meaningfully engage with career-related information for the purpose of using it in career decision-making. Career readiness is preparing students for gainful employment. Career literacy precedes career readiness as a way to help students meaningfully understand and undertake the career preparation required for their desired careers.

An assessment of career literacy skills will inform teachers and parents of the students' abilities and needed areas of improvement. As a result of improving a student's career literacy, students may be able to make decisions from a perspective informed by more than their surroundings. Parents are the most significant influence on students' career selections (Liu et al., 2020); however, the connection among communities, schools, and achievement can be leveraged by providing schools and parents with an assessment of their students' career literacy. Appropriate interventions can be developed and implemented to provide the best possible postsecondary outcomes for today's youth.

The Strengthening Career and Technical Education Act for the $21^{\text {st }}$ Century Act (Perkins $\mathrm{V}$; 2018) more clearly defines the purpose of career and technical education to include academic knowledge, and it also has added the need for employability skills. This change emphasizes the importance of employability skills in career preparation. Specifically, the incorporation of employability skills creates a need to infuse career literacy skills in the career preparation curriculum. Those who lack career literacy skills as a precursor may struggle to adequately acquire employability skills.

The rising cost of college tuition, mounting debt of college graduates, and the uncertain job market for students after college graduation makes it critical for students to understand and be able to make decisions about careers prior to the completion of their secondary education (Symonds et al., 2011). Gottfredson (2005) posited that students begin to discount themselves from certain careers in early adolescence. Therefore, it becomes increasingly important to make sure they have or begin developing the skill set necessary no later than middle school to ensure that they will be able to make the most appropriate, informed choices based on the relevant career-related information and experiences available to them. Students' preparation and understanding varies based on their lived experiences from early adolescence, up to and possibly beyond the conclusion of their secondary education. This skill set is developed informally 
Valentine and Kosloski: Developing the Key Constructs of Career Literacy: A Delphi Study

throughout a student's academic career as a result of their exposure to experiences, individuals, and sought-after information (Choi, 2015; Tang et al., 2008).

\section{Theoretical Framework}

Although the two critical factors most influencing a high school student's career development are experiences and self-efficacy, Social Cognitive Career Theory (SCCT) additionally examines outcome expectations and goals as they relate to how students make career choices (Lent et al., 2017). According to Lent et al. (1994), Social Cognitive Career Theory was developed to connect several career development and decision-making theories as an expansion of Bandura's Social Cognitive Theory. The three main tenets of SCCT, self-efficacy, outcome expectations, and goals, are interwoven throughout a student's career development and decisionmaking processes. This study extracts one of the three tenets, self-efficacy, and offers the development of career literacy as a way to potentially increase a student's self-efficacy in careerrelated decision making.

Self-efficacy, a critical factor in career development, plays several roles in decision making. Students' career outlooks are influenced by both positive and negative experiences surrounding their perceptions of what they feel they can and cannot accomplish, which in turn affects their outcome expectations in a situation (Kay et al., 2017; Lent et al., 1994). Along the same lines, perceived self-efficacy has a significant impact on behaviors and commitment (Guillon et al., 2004). In a positive sense, a student's self-efficacy is a factor for reaching toward opportunities. On the other hand, perceived barriers affect self-efficacy negatively, leading to the elimination of viable career options in the absence of positive interventions (Turner et al., 2019). While this theory focuses on career development and decision making, career literacy is a precursor to successfully engaging in those actions.

New literacy theories converge to posit that students need more than the academic literacy that is measured on a state assessment in school to be successful in the world (Bennett \& Robertson, 2015; Cook, 2002; Street, 2003). Successful citizens must possess not only academic literacy (school literacy), but also digital literacy, information literacy, food and nutrition literacy, and even menu board literacy, to name a few, to make appropriate, informed decisions about tasks over which they have control and responsibility (Bennett \& Robertson, 2015; Cameron et al., 2007; Doustmohammadian et al., 2017; Street, 2003; Williams et al., 2017).

The definition of literacy has evolved since the beginning of compulsory education to meet the changing needs of society. Several literacies have been identified as important to everyday life and highlight the ability to not only read words, but also interpret them in the context of a given situation through multiple modalities. The term career literacy is often used synonymously with the term "career readiness," but as noted, this is considerably different than how it has been developed for the purpose of this study.

The definition of career literacy used here is a synthesis of definitions established for information and communication technology, health, and food and nutrition literacies. The definition of food and nutrition reflects a multi-dimensional, progressive approach to the knowledge and skills adolescents would need to acquire and use to, ultimately, make wellinformed decisions regarding their meal choices (Doustmohammadian et al., 2017). It also aligns with the definition of literacy established by the United Nations (2017) with its sustainable goal number 4, "the ability to identify, understand, interpret, create, communicate and compute using printed and written materials associated with varying contexts." For this research, career literacy 
is defined as the functional, interactive, and critical skills a student needs to be able to understand, interpret, evaluate, and make decisions on career-related information (Doustmohammadian et al., 2017; Larsen, 2007; Lau \& Yuen, 2014; Vidgen \& Gallegos, 2014). Therefore, in this context, career literacy is a precursor to career readiness.

In line with the studies of multiple literacies, the authors intend to not only add evidence supporting the inclusion of career literacy as a necessary component of students' education, but also add empirical data validating the skill set required. This study aims to determine the skills required to demonstrate mastery of career literacy which would help educators and parents recognize a student's capacity for evaluating career-related information and provide the appropriate intervention for moving students along the career literacy continuum.

\section{Purpose and Objectives}

The purpose of this study was to determine the knowledge and skills required for career literacy and to develop the progression of skills. With this information, educators and stakeholders will be able to assess a student's performance and provide student specific recommendations for future experiences that will further develop their career literacy. In order to do that, this study is framed by the following research objectives:

1. Identify the skills adolescents should possess or concepts they should know to be considered career literate.

2. Develop an ordinal acquisition continuum of career literacy skills.

\section{Literature Review}

Students develop two of the cognitive skills necessary to begin to make career decisions-self-concept and perceptions about occupation -- during adolescence (Gottfredson, 2005). At the same time, students' vocational interests begin to stabilize (Gibbons \& Shoffner, 2004). If, at adolescence, students are no longer considering the full range of career options available to them, they are likely to exclude career options that may lead to higher wage-earning positions (Gottfredson, 2005). Adding equity into consideration means that students, especially those in low-income or impoverished schools, will continue to prepare for lower-earning positions (Leland et al., 2007). This peril of exclusion holds especially true for female students who often exclude themselves from non-traditional roles that may earn higher wages (Bonett, 1994). In order to combat this cycle, students need to develop a sound basis for making decisions about career preparation.

Educators, parents, and personal experiences are critical to building a student's capacity to make informed career decisions (Choi, 2015; Tang et al., 2008). According to Tang et al., (2008), learning experiences have a significant impact on a student's self-efficacy, even more so on female students than male students. While counselors are tasked with career development, group learning experiences about career opportunities are not effective unless a student chooses to be a part of a group, indicating a vested interest in the process (Guillon et al., 2004). Building capacity in students to process and more effectively make choices about their post-secondary lives requires an intentional effort to provide targeted learning opportunities specific to their individual areas of need. In some communities, a knowledge void exists surrounding career development, and one way to begin to bridge the equity gap is to provide education and programming to parents in support of their students (Godbey \& Gordon, 2019). It is in the effort 
to build capacity that it becomes necessary to more clearly define the knowledge and skills needed for the establishment of career literacy which is different than career readiness. In the same way that literacy skills are part of a student's preparedness to enter school, career literacy is a set of skills that needs to be developed prior to expecting a student to be college and career ready. Measuring this information about a student will provide educators and parents with data about specific areas of improvements for students individually.

Guillon et al. (2004) pointed out that students who are committed to the career development process are more likely to pursue opportunities for learning. When the stakeholders, especially students, determine what assistance is needed, they can begin to engage in specific personal learning conversations that will ultimately increase their level of career literacy. As a result of defining and measuring career literacy, educators and parents will be able to identify and provide specific resources students need to address their deficit areas (Tang et al., 2008). The skill definitions can also be used for career and technical education, career development program evaluation, and for determining future learning outcomes for specific students along with the collective school community (Brumwell et al., 2017).

The authors of Pathways to Prosperity projected that American youth would have diminishing career opportunities - even with college degrees-- and more significant barriers would exist for students who neglected to complete high school (Symonds et al., 2011). Underserved youth with low-income and minority status are the most negatively impacted by the current projected employment situation. Gibbons and Shoffner (2004) indicated that youth career choice and development remain fluid until students reach adolescence, in the absence of a significant influencing event. Among the recommendations for influencing the pendulum to swing more favorably is an intentional focus on the preparation of youth for their post-secondary experiences (Symonds et al., 2011). One way to do this is to begin preparing them for these experiences earlier, by providing them with tools and exploratory opportunities not later than the beginning of adolescence (McFadden \& Curry, 2018; Super, 1953; Tang et al., 2008).

According to Brumwell et al. (2017), assessment, and the resulting feedback, is one tool that educators can use to improve the delivery of instruction and services to students. Currently, assessments administered in high school are available to measure students' college and career readiness skills (Lapan et al., 2017). College and career assessments generally focus on a student's ability to successfully access college-related texts and perform work-related tasks (Mishkind, 2014). High school students are required to make critical decisions concerning their course selections to graduate as early as $8^{\text {th }}$ grade, at times making difficult choices between electives, enrichment courses, or more rigorous coursework. High school may be too late for students to take action on necessary post-secondary preparation based on the results of a college and career readiness diagnostic (Julien, 1999). However, while scales exist to measure areas of a student's career development such as interests, efficacy, and readiness, the researchers have found no one particular measure is available to determine where a student falls along the career literacy continuum or their preparation to understand, interpret, evaluate, and make decisions based on career-related information.

\section{Methods}

This study used a four-round, ranking-style Delphi administered using email and an electronic platform, Qualtrics, to determine the knowledge and skills students should possess in

order to be considered career literate. Career literacy, as defined in this research, has not yet been 
defined by a specific set of characteristics, but is an amalgamation of parallel definitions of other literacies and is defined as the functional, interactive, and critical skills a student needs to be understand, interpret, evaluate, and make decisions on career-related information (Doustmohammadian et al., 2017; Larsen, 2007; Lau \& Yuen, 2014; Vidgen \& Gallegos, 2014). The Delphi method was used to determine the skills necessary for career literacy and also provide a sound basis for the future exploration and development of career literacy as one of the literacies students need to achieve post-secondary career success (Pare et al., 2013). The exploratory nature of the Delphi method provided researchers with an opportunity to facilitate consensus among experts using a specific set of criteria, which is a valuable way to establish new constructs (Okoli \& Pawlowski, 2004; Paré et al., 2013). The four main features of the Delphi method include, "anonymity, iteration, controlled feedback, and statistical group response," and allow ideas to be gathered and quantified (Habibi et al., 2014, p.8).

Delphi research is used by social science researchers as a way to combat some of the challenges that exist in focus group research. The Delphi method provides participants with the opportunity to provide initial responses without knowledge of or regard to the position or status of others in the group, on their own time (Geist, 2010; Hsu \& Sanford, 2007). Additionally, it provides an opportunity for geographically diverse perspectives to be included which can contribute to the richness of the study's results without the costs of travel or time.

As with any research, establishing the validity and reliability of this study is of paramount importance. One way to improve the internal validity of this Delphi study was the use of an expert review board who reviewed and aggregated participants' responses from open-ended questions to eliminate the opportunity for researcher bias in the brainstorming phases. At each iteration the participants were reminded that we sought their personal opinions and provided them with the opportunity to note critical missing concepts in Round 2.

\section{Participants}

Special attention was taken to craft a subject matter expert (SME) panel that would lend additional validity to the study. According to Wester and Borders (2014), the results of the study can be affected by the strength and expertise of the SME panel. The selection of the most appropriate SME panel provided protection against potential validity issues, like attrition, which could affect response bias (Gill, 2013; Paré et al., 2013). Participants with a stake in the results are more likely to participate throughout the lengthy process (Rowe \& Wright, 2011). The sought-after expert panel needed to represent a largely homogeneous set of skills. The target number of panel members was between 15-18, deemed acceptable in a Delphi study (Kezar \& Maxey, 2016).

In keeping consistent with the literature, the Delphi panel consisted of a purposively selected sample of subject matter experts (SME). The selections were made based on individuals who met the following qualifications:

- have a stake in the results of the research, (Hsu \& Sanford, 2007; Preble, 1984)

- have first-hand knowledge and experience with the subject, (Hsu \& Sanford, 2007),

- held specific titles indicating leadership in career and technical education, (Holloway, 2012),

- have contributed to the literature in the field, (Hsu \& Sanford, 2007), and

- represent a diverse cross-section geographically (Gill, 2013). 
A purposive sample was used to initiate the study, and participants were asked to nominate other potentially eligible participants, providing a snowball effect. Any prospective panel member recommended would be vetted for eligibility based on the same criteria. In order to obtain a geographically diverse sample for the expert members of the Delphi panel, the United States, and its territories, including the Virgin Islands, were broken into the four quadrants used by the U.S. Census Bureau. The selected individuals were organized and balanced by quadrant.

The researchers sought individuals deemed to be critical to the curricular design and/or decision-making process for career education at the school district or state level, community workforce liaison partners, or Ph.D. holding researchers who have recently published in a related field. Because qualified participants may have been found in a variety of professional roles, the researchers initiated contact with those prospective participants found in various locations, including: career and technical education student organization state directors and administrators lists, state boards of education websites, school division websites in the top 10 most populated cities in the U.S., and the U.S. Department of Labor's Workforce Development, CareerOneStop. Because position titles vary, individuals with job descriptions similar to that of Director of Career and Technical Education, Director of Counseling, workforce readiness youth counselor, youth employment specialist, career counselor, business liaison to K-12, and secondary counselors were sought after for the panel by making initial contacts within the researcher's personal network and asking for expert referrals and reviewing advisory boards of CTE student organizations. Prospective participants were initially contacted via email, and all solicited prospective professionals were asked to provide referrals based on the five criteria noted above.

\section{Procedures}

The selected expert panelists were contacted to request their commitment to participate in the study. In Round 1, participants were sent an email with a link to electronically access the survey. The survey provided participants with the definition of career literacy, including definitions and descriptions of each domain - functional, interactive, and critical - and the purpose for determining the skills and/or tasks that students should be able to perform. Additionally, the form asks the respondents to reply to the following three open-ended statements to gain their original thoughts.

1. Statement 1: Please share two knowledge concepts or skills that should be required for students to be considered functionally career literate.

2. Statement 2: Please share two knowledge concepts or skills that should be required for students to be considered interactively career literate.

3. Statement 3: Please share two knowledge concepts or skills that should be required for students to be considered critically career literate.

The brainstorming results from Round 1 were reviewed by an expert review board for the purpose of identifying overlap in and aggregating panelists' responses. The review board for this study included a graduate professor with a research agenda specializing in workforce development and K-12 education. In addition to the professor, the review board included a doctoral student with a research agenda specializing in career and technical education. This board aggregated the responses by question, taking into account ideas that were similar and/or overlapping, and developed a comprehensive list of the skills and tasks provided by the panelists in Rounds 1 and 2, ensuring that all responses were captured and duplication was eliminated. 
The purpose of Round 2 was to provide panelists the opportunity to determine what, if any, additional concepts and skills should be included on the list. At the beginning of the round, participants received a copy of their responses from Round 1 and the resulting comprehensive list by question. They were asked to review the responses for each question and include any missing concepts or skills that were important to the list that had been omitted. The expert review board again analyzed the data, checked for overlap, aggregated the responses, and added any newly represented skills to the lists by question.

During Round 3, the panelists received their own Round 2 responses, in addition to the aggregated responses by question, in a survey format. In this round, the panelists reviewed the presented list of skills and ranked the importance of the skills using a Likert-type scale of $1-5$, with $1=$ not important, $2=$ limited importance, $3=$ moderate importance, $4=$ significant importance, and $5=$ most important. Additionally, the panelists were also asked to indicate the most appropriate school level for introduction of the skills: middle school, high school, or after high-school graduation.

The results of Round 3 were statistically analyzed to determine each skill's level of importance, consensus, and the most appropriate grade for introduction. The acceptable levels for consensus were established prior to the study (Meijering et al., 2013). In order to determine the importance of the skills and an initial level of consensus, the mean score and the interquartile range (IQR) were calculated. In order to be retained on the list, skills must have ranked at least moderately important, $M \geq 3.5$ (Martin \& Ritz, 2012). Skills with IQR $\leqq 1.00$ were retained because they suggest consensus among the panelists (Childress \& Rhodes, 2006). The appropriate grade for introduction was analyzed for the mean as a separate element with no impact on the retention of the skill. Items not meeting the retention criteria were removed from the list prior to being sent out for consideration in Round 4.

At the beginning of Round 4, the participants received a copy of their Round 3 responses, along with the group means by question for both the importance and the appropriate school level for initial exposure of the concepts and skills. The final request of the panelists was to review of the list of skills, update any rankings, if desired, and provide any final feedback. The results were analyzed using the a priori elimination criteria. The coefficient of variance $(\mathrm{CV})$ was calculated with a priori levels set at $.00-.50$ to indicate consensus among experts for the final results. Because school levels did not directly translate to a grade (options were middle school, high school, and postsecondary), school level results were also analyzed by mode. Both the mean and the median could be skewed by outliers and not illustrate the intent of the majority.

\section{Results}

The initial round of invitations was mailed to 21 candidates. Six accepted the initial invitation and an additional five accepted as a result of the reminder. The initial invitations did not result in enough participants. Therefore, in addition to seeking additional participants, the individuals who had already committed to participate were asked to provide the names of others who met the requirements of the study. An additional eight candidates were contacted from the researchers' list. One accepted and nine of the candidates recommended by the participants were contacted. All accepted for a total of 21 participants.

The participating panelists represented a closely connected cross-section of experienced professionals who have engaged with secondary students in a work or career advising capacity or have done extensive research on workforce development for youth. The common characteristics 
include at least five or more years of experience working with or advising K - 12 students, working in a capacity as a liaison or advisor between $\mathrm{K}-12$ students and the business/industry community, or have published in peer-reviewed journals with a focus on workforce development or career preparation (Vogel \& Zwolinsky, 2019).

Round 1. Of the 21 experts invited to participate, 17 completed Round 1 (81\% response rate) and four were lost to attrition. Each of the responding 17 panelists provided two answers to each of the three questions for a total of 102 responses. The results were provided to the expert review board who analyzed the responses and aggregated similar responses by question. At the conclusion of their collaboration, the responses were grouped by domain with 16 functional, 19 interactive, and 23 critical unique skills for an aggregated list of 58 initial skills and concepts. The results of Round 1 were categorized by each of the three questions for participants to review in the next round.

Round 2. In Round 2, responses were received from 16 of 17 participants in Round 2 (94\% response rate), and one was lost to attrition. Each panelist was emailed the list of 58 concepts and skills. They were invited to review the list and add missing skills or concepts, if needed, or report back with no changes. The participants recommended a total of six additional skills. One recommendation was a restatement of a concept in the previously established list and was not added. Five new traits were added, bringing the total number of items to 63 . The responses from Round 2 were grouped by each of the three questions and entered into Qualtrics in preparation for ranking in the next round.

Table 1. Knowledge and skills reported in Round 2.

\begin{tabular}{lll}
\hline \multicolumn{1}{c}{ Functional } & \multicolumn{1}{c}{ Interactive } \\
\hline Concepts & Adjudicate facts versus opinions & $\begin{array}{l}\text { Acknowledge expertise/experience } \\
\text { as beneficial qualities to seek in } \\
\text { career advisors }\end{array}$ \\
& $\begin{array}{l}\text { Explain the philosophy and nature } \\
\text { of "work" }\end{array}$ & $\begin{array}{l}\text { Acknowledge the importance of } \\
\text { persistence and follow through }\end{array}$ \\
$\begin{array}{l}\text { Knowledge of basic financial } \\
\text { literacy concepts and their }\end{array}$ & $\begin{array}{l}\text { Indicate how different skill sets } \\
\text { and predispositions relate to } \\
\text { Knonnections to work }\end{array}$ \\
$\begin{array}{l}\text { job outlooks and how Career } \\
\text { Clusters and Pathways are } \\
\text { connected to career exploration }\end{array}$ & $\begin{array}{l}\text { Interpret professional etiquette } \\
\text { expectations (communication, } \\
\text { attire, topics, etc.), as well as how } \\
\text { those expectations may vary from } \\
\text { one career to another }\end{array}$ \\
$\begin{array}{l}\text { Knowledge of the elements of } \\
\text { good teamwork, as well as the } \\
\text { importance of working on a team }\end{array}$ & $\begin{array}{l}\text { Knowledge of one's own past } \\
\text { triggers, as a precursor to } \\
\text { managing professional demeanor } \\
\text { in a given environment }\end{array}$ \\
& $\begin{array}{l}\text { Take the initiative to seek out } \\
\text { career information and discuss it }\end{array}$ \\
&
\end{tabular}
career information and discuss it

Identify basic requirements of a job to determine whether one meets said requirements

Identify the steps needed to gain the required skills toward entry into a career 
Translate career progressions and different steps within a career ladder

Use one's own discernment, empathy, and grit in communication and goal setting

Utilize feedback and advice to advance one's range of career opportunities

View things from others' perspectives, understanding that interactions with others often have little to do with oneself and more to do with others

Interactive

Skills Analyze simple and complex written instructions to perform a task

Analyze the credibility of a source of information

Apply what has been read to realworld situations

Articulate skills possessed through the completion of a resume

Complete a job application

Conduct career research and determine educational/ physical requirements for a position

Decipher information presented in different forms (orally, written, visually, etc.)

Draw inferences to, or make connections with information

Effectively communicate orally and in writing related to work performance

Interpret information from datasets, or others graphical representations of data Interpret technical reading pieces
Articulate ones' own skills/values, transferable skills, and career goals

Ask the "right" questions to seek answers, provide clarity, or to problem-solve

Communicate personal career interests and discuss career opportunities with prospective employers and other influencers

Communicate with experienced people with respect to a given career field

Contact, obtain permission, and prepare a list of professional references appropriate for a specific job opportunity Initiate the interview follow-up process

Knowledge of appropriate vernacular by audience (codeswitching)

Knowledge of your own bias and its impact on your assumptions and interpretations

Listen thoroughly, show empathy, and a genuine effort to interpret the speaker's perspective, both implicitly and explicitly

Read, process, and interpret career information regarding employment

Relay labor market information to others
Immerses oneself in field experiences or similar environments to gain a better understanding of a career Interpret organizational culture and demonstrate how to foster a healthy culture

Knowledge of the impact selfmotivation and confidence have on growth

Self-assess with honesty and forthrightness

\section{Critical}

Ability to determine the overall financial cost to prepare for a career

Advocate for oneself with respect to ones' career (ex. calling to schedule an interview)

Align resources and work towards an organizations' mission, vision, and goals

Analyze an environment to address barriers to career entry

Apply written, verbal, and digital information to solve problems

Ask questions that will expand the narrative and discussion in an organization

Collaborate with others and be open to other's ideas

Conduct career research to inform career decisions

Exercise emotional intelligence and empathy

Exercise mental agility during conversation with career influencers

Match ones' own values, interests, and skills, with a compatible career 
Manipulate basic math functions, exemplifying data literacy
Speak articulately and generally communicate orally in a professional manner

Work collaboratively with diverse groups
Relate ones' own academic/skill portfolio with desirable career paths

Utilize the scientific method in order to analyze, strategize, and problemsolve

Round 3. All 16 participants responded to Round 3 (100\% response rate). In order to begin the process of quantifying the consensus of the group, panelists were asked to rank both the importance of each item $(1=$ least important, $5=$ most important $)$ and the grade level most appropriate for initial exposure of each item $(1=$ middle school, $2=$ high school, and $3=$ postsecondary school).

The acceptable levels for consensus were established prior to the study based on literature related to Delphi studies (Meijering et al., 2013). In order to determine the importance of the career literacy skills the means were calculated. Items with a mean of 3.5 or higher $(M \geq 3.5)$ were retained as relevant (Martin \& Ritz, 2012). Items meeting the initial consensus criteria IQR $\leq 1.0$, were retained for Round 4 (Childress \& Rhodes, 2006). Items not meeting both criteria were removed from the list of responses for Round 4. The appropriate school level for introduction of a concept was analyzed for the mean and mode with no impact on the retention of the skill. The mode is reported as the most accurate representation of the panel's recommendation for the appropriate grade-level for introduction of each skill.

The skills' importance data were analyzed for mean, median, standard deviation, and interquartile range $(I Q R)$. All items with $M>3.5$ were retained for the next round, and those not meeting the threshold, indicating less than moderate importance, were removed from the list. Eight items fell below the previously established mean. Three items were removed for scores above the a priori level, $I Q R>1.0$, indicating a lack of consensus amongst the panelists.

Round 4. The remaining 16 panelists were emailed their individual responses as well as the group's collective responses by question by means. They were asked to review their responses in the context of the group responses and make changes as appropriate or respond with "no changes." At the conclusion of Round 4, four participants indicated changes. Two of the participants made changes which updated responses they left blank in Round 3. The results were analyzed using the a priori elimination criteria. In addition, the coefficient of variance $(\mathrm{CV})$ was calculated with a priori levels set at .00 - .50 to indicate consensus among experts for the final results (English \& Kernan, 1976). 
Table 2. Round 3 Items Removed.

\begin{tabular}{|c|c|c|c|}
\hline Career Literacy Skill Description & $M<3.5$ & Career Literacy Skill Description & $I Q R>1$ \\
\hline Relay labor market information to others & 2.38 & $\begin{array}{l}\text { Conduct career research and determine } \\
\text { educational/ physical requirements for a } \\
\text { position }\end{array}$ & 2.00 \\
\hline $\begin{array}{l}\text { Analyze the value of an organization's } \\
\text { mission, vision, and goals }\end{array}$ & 3.19 & $\begin{array}{l}\text { Knowledge of basic financial literacy } \\
\text { concepts and their connections to work }\end{array}$ & 1.50 \\
\hline $\begin{array}{l}\text { Exercise mental agility during conversation } \\
\text { with career influencers }\end{array}$ & 3.19 & $\begin{array}{l}\text { Knowledge of the impact self-motivation } \\
\text { and confidence have on growth }\end{array}$ & 1.50 \\
\hline Explain the philosophy and nature of "work" & 3.33 & & \\
\hline $\begin{array}{l}\text { Interpret organizational culture and } \\
\text { demonstrate how to foster a healthy culture }\end{array}$ & 3.38 & & \\
\hline $\begin{array}{l}\text { Align resources and work towards an } \\
\text { organizations' mission, vision, and goals }\end{array}$ & 3.38 & & \\
\hline $\begin{array}{l}\text { Utilize the scientific method in order to } \\
\text { analyze, strategize, and problem-solve }\end{array}$ & 3.44 & & \\
\hline Initiate the interview follow-up process & 3.44 & & \\
\hline
\end{tabular}

The final data were statistically analyzed. The final list of items met the following criteria: $M \geq 3.5, I Q R \leq 1.0$, and $C V<.50$. Any items that did not meet all criteria were removed from the list. An analysis of the changes made in Round 4 indicated the removal of two additional items that did not reach consensus by the panel IQR $>1.0$. See Table 3 for the removed items and Table 4 for the complete list of skills.

Throughout the course of the study the responses were analyzed as three separate questions representing each of the three domains of career literacy: functional, interactive, and critical. After conducting Round 4, the list of concepts and skills was aggregated without respect to domain, and the results were reported by mean in descending order of the importance of the traits. At the conclusion of Round 4, 15 of 16 participants had responded (94\% response rate). This study retained 15 of its original 21 panelists, resulting in an overall $71 \%$ retention rate. The literature suggests a Delphi study that maintains participation of at least $70 \%$ of the invited experts is good (Vogel et al., 2019).

Table 3. Round 4 Items Removed.

\begin{tabular}{lc}
\hline Career Literacy Skill Description & $I Q R>1$ \\
\hline Draw inferences to, or make connections with information & 1.25 \\
Interpret technical reading pieces & 1.25 \\
\hline
\end{tabular}


Table 4. Final Career Literacy Delphi Results. Round 4.

\begin{tabular}{|c|c|c|c|c|c|c|c|c|}
\hline Description & $\begin{array}{c}\text { Importance } \\
M\end{array}$ & $S D$ & $C V$ & $I Q R$ & $\begin{array}{c}\text { Continuum } \\
M\end{array}$ & $\begin{array}{l}\text { Continuum } \\
M d n\end{array}$ & $\begin{array}{l}\text { Continuum } \\
\text { Mode }\end{array}$ & $\begin{array}{l}\Delta \text { Importance } M \\
\text { R3 to R4 }\end{array}$ \\
\hline $\begin{array}{l}\text { Decipher information presented in } \\
\text { different forms (orally, written, } \\
\text { visually, etc.) }\end{array}$ & 4.81 & 0.39 & 0.08 & 0.00 & 1.25 & 1.0 & 1 & 0.01 \\
\hline $\begin{array}{l}\text { Work collaboratively with diverse } \\
\text { groups }\end{array}$ & 4.69 & 0.58 & 0.12 & 0.25 & 1.13 & 1.0 & 1 & 0.00 \\
\hline $\begin{array}{l}\text { Knowledge of the elements of good } \\
\text { teamwork, as well as the importance } \\
\text { of working on a team }\end{array}$ & 4.50 & 0.61 & 0.14 & 1.00 & 1.25 & 1.0 & 1 & -0.03 \\
\hline $\begin{array}{l}\text { Effectively communicate orally and } \\
\text { in writing related to work } \\
\text { performance }\end{array}$ & 4.50 & 0.50 & 0.11 & 1.00 & 1.44 & 1.0 & 1 & -0.03 \\
\hline $\begin{array}{l}\text { Analyze simple and complex written } \\
\text { instructions to perform a task }\end{array}$ & 4.50 & 0.50 & 0.11 & 1.00 & 1.19 & 1.0 & 1 & 0.03 \\
\hline $\begin{array}{l}\text { Identify the steps needed to gain the } \\
\text { required skills toward entry into a } \\
\text { career }\end{array}$ & 4.44 & 0.70 & 0.16 & 1.00 & 2.13 & 2.0 & 2 & 0.00 \\
\hline $\begin{array}{l}\text { Collaborate with others and be open } \\
\text { to other's ideas }\end{array}$ & 4.44 & 0.79 & 0.18 & 1.00 & 1.13 & 1.0 & 1 & 0.00 \\
\hline $\begin{array}{l}\text { Speak articulately and generally } \\
\text { communicate orally in a professional } \\
\text { manner }\end{array}$ & 4.44 & 0.61 & 0.14 & 1.00 & 1.69 & 2.0 & 2 & 0.00 \\
\hline $\begin{array}{l}\text { Self-assess with honesty and } \\
\text { forthrightness }\end{array}$ & 4.38 & 0.86 & 0.20 & 1.00 & 1.69 & 2.0 & 2 & 0.00 \\
\hline $\begin{array}{l}\text { Apply written, verbal, and digital } \\
\text { information to solve problems }\end{array}$ & 4.38 & 0.86 & 0.20 & 1.00 & 1.13 & 1.0 & 1 & 0.00 \\
\hline $\begin{array}{l}\text { Knowledge of your own bias and its } \\
\text { impact on your assumptions and } \\
\text { interpretations }\end{array}$ & 4.38 & 0.86 & 0.20 & 1.00 & 1.56 & 1.5 & 1 & 0.00 \\
\hline $\begin{array}{l}\text { Exercise emotional intelligence and } \\
\text { empathy }\end{array}$ & 4.31 & 0.77 & 0.18 & 1.00 & 1.56 & 1.5 & 1 & 0.00 \\
\hline $\begin{array}{l}\text { Apply what has been read to real- } \\
\text { world situations }\end{array}$ & 4.25 & 0.56 & 0.13 & 1.00 & 1.50 & 1.0 & 1 & -0.02 \\
\hline $\begin{array}{l}\text { Acknowledge the importance of } \\
\text { persistence and follow through }\end{array}$ & 4.25 & 0.83 & 0.20 & 1.00 & 1.38 & 1.0 & 1 & 0.00 \\
\hline $\begin{array}{l}\text { View things from others' } \\
\text { perspectives, understanding that } \\
\text { interactions with others often have } \\
\text { little to do with oneself and more to } \\
\text { do with others }\end{array}$ & 4.25 & 0.83 & 0.20 & 1.00 & 1.88 & 2.0 & 2 & 0.00 \\
\hline Adjudicate facts versus opinions & 4.19 & 0.63 & 0.15 & 1.00 & 1.50 & 1.0 & 1 & -0.01 \\
\hline $\begin{array}{l}\text { Analyze the credibility of a source of } \\
\text { information }\end{array}$ & 4.19 & 0.73 & 0.17 & 1.00 & 1.44 & 1.0 & 1 & -0.08 \\
\hline $\begin{array}{l}\text { Listen thoroughly, show empathy, } \\
\text { and a genuine effort to interpret the } \\
\text { speaker's perspective, both implicitly } \\
\text { and explicitly }\end{array}$ & 4.19 & 0.81 & 0.19 & 1.00 & 1.56 & 2.0 & 2 & 0.00 \\
\hline $\begin{array}{l}\text { Articulate ones' own skills/values, } \\
\text { transferable skills, and career goals }\end{array}$ & 4.19 & 0.73 & 0.17 & 1.00 & 2.06 & 2.0 & 2 & 0.00 \\
\hline $\begin{array}{l}\text { Identify basic requirements of a job } \\
\text { to determine whether one meets said } \\
\text { requirements }\end{array}$ & 4.13 & 0.70 & 0.17 & 1.00 & 2.00 & 2.0 & 2 & 0.00 \\
\hline
\end{tabular}




\begin{tabular}{|c|c|c|c|c|c|c|c|c|}
\hline Description & $\begin{array}{c}\text { Importance } \\
M\end{array}$ & $S D$ & $C V$ & $I Q R$ & $\begin{array}{c}\text { Continuum } \\
M\end{array}$ & $\begin{array}{l}\text { Continuum } \\
\qquad M d n\end{array}$ & $\begin{array}{l}\text { Continuum } \\
\text { Mode }\end{array}$ & $\begin{array}{c}\Delta \text { Importance } M \\
\text { R3 to R4 }\end{array}$ \\
\hline $\begin{array}{l}\text { Use one's own discernment, } \\
\text { empathy, and grit in communication } \\
\text { and goal setting }\end{array}$ & 4.13 & 1.05 & 0.26 & 1.00 & 1.88 & 2.0 & 2 & 0.00 \\
\hline $\begin{array}{l}\text { Interpret professional etiquette } \\
\text { expectations (communication, attire, } \\
\text { topics, etc.), as well as how those } \\
\text { expectations may vary from one } \\
\text { career to another }\end{array}$ & 4.13 & 0.78 & 0.19 & 1.00 & 1.94 & 2.0 & 2 & 0.00 \\
\hline $\begin{array}{l}\text { Knowledge of appropriate vernacular } \\
\text { by audience (code-switching) }\end{array}$ & 4.13 & 1.05 & 0.26 & 1.00 & 2.21 & 2.0 & 2 & 0.00 \\
\hline $\begin{array}{l}\text { Immerses oneself in field experiences } \\
\text { or similar environments to gain a } \\
\text { better understanding of a career }\end{array}$ & 4.06 & 0.66 & 0.16 & 0.25 & 2.06 & 2.0 & 2 & 0.06 \\
\hline $\begin{array}{l}\text { Match ones' own values, interests, } \\
\text { and skills, with a compatible career }\end{array}$ & 4.06 & 0.56 & 0.14 & 0.00 & 1.81 & 2.0 & 2 & 0.06 \\
\hline $\begin{array}{l}\text { Ability to determine the overall } \\
\text { financial cost to prepare for a career }\end{array}$ & 4.00 & 0.61 & 0.15 & 0.00 & 2.00 & 2.0 & 2 & 0.00 \\
\hline $\begin{array}{l}\text { Relate ones' own academic/skill } \\
\text { portfolio with desirable career paths }\end{array}$ & 3.94 & 0.56 & 0.14 & 0.00 & 1.94 & 2.0 & 2 & 0.00 \\
\hline $\begin{array}{l}\text { Communicate personal career } \\
\text { interests and discuss career } \\
\text { opportunities with prospective } \\
\text { employers and other influencers }\end{array}$ & 3.94 & 0.56 & 0.14 & 0.00 & 2.25 & 2.0 & 2 & 0.00 \\
\hline $\begin{array}{l}\text { Analyze ones' role in a specific task } \\
\text { or work environment }\end{array}$ & 3.81 & 0.81 & 0.21 & 1.00 & 2.06 & 2.0 & 2 & 0.00 \\
\hline $\begin{array}{l}\text { Ask questions that will expand the } \\
\text { narrative and discussion in an } \\
\text { organization }\end{array}$ & 3.81 & 0.81 & 0.21 & 1.00 & 2.44 & 3.0 & 3 & 0.00 \\
\hline $\begin{array}{l}\text { Manipulate basic math functions, } \\
\text { exemplifying data literacy }\end{array}$ & 3.81 & 0.95 & 0.25 & 0.25 & 1.06 & 1.0 & 1 & -0.05 \\
\hline Complete a job application & 3.81 & 0.63 & 0.17 & 1.00 & 2.00 & 2.0 & 2 & 0.01 \\
\hline $\begin{array}{l}\text { Read, process, and interpret career } \\
\text { information regarding employment }\end{array}$ & 3.81 & 0.63 & 0.17 & 1.00 & 2.13 & 2.0 & 2 & 0.00 \\
\hline $\begin{array}{l}\text { Ask the "right" questions to seek } \\
\text { answers, provide clarity, or to } \\
\text { problem-solve }\end{array}$ & 3.81 & 1.07 & 0.28 & 0.50 & 1.94 & 2.0 & 2 & 0.00 \\
\hline $\begin{array}{l}\text { Analyze ones' own self values, skills, } \\
\text { apprehensions, fears, knowledge, and } \\
\text { incompatible work settings, and how } \\
\text { these things play a role in ones' } \\
\text { success within a particular position }\end{array}$ & 3.75 & 0.82 & 0.22 & 0.50 & 2.00 & 2.0 & 2 & -0.25 \\
\hline $\begin{array}{l}\text { Conduct career research to inform } \\
\text { career decisions }\end{array}$ & 3.75 & 0.56 & 0.15 & 1.00 & 1.75 & 2.0 & 2 & 0.00 \\
\hline $\begin{array}{l}\text { Knowledge of career options and job } \\
\text { outlooks and how Career Clusters and } \\
\text { Pathways are connected to career } \\
\text { exploration }\end{array}$ & 3.75 & 0.75 & 0.20 & 1.00 & 1.50 & 1.0 & 1 & -0.05 \\
\hline $\begin{array}{l}\text { Articulate skills possessed through } \\
\text { the completion of a resume }\end{array}$ & 3.75 & 0.66 & 0.18 & 1.00 & 2.00 & 2.0 & 2 & -0.05 \\
\hline $\begin{array}{l}\text { Interpret information from datasets, } \\
\text { or others graphical representations of } \\
\text { data }\end{array}$ & 3.75 & 0.75 & 0.20 & 1.00 & 1.50 & 1.0 & 1 & -0.05 \\
\hline
\end{tabular}




\begin{tabular}{|c|c|c|c|c|c|c|c|c|}
\hline Description & $\begin{array}{c}\text { Importance } \\
M\end{array}$ & $S D$ & $C V$ & $I Q R$ & $\begin{array}{c}\text { Continuum } \\
M\end{array}$ & $\begin{array}{l}\text { Continuum } \\
\qquad d n\end{array}$ & $\begin{array}{l}\text { Continuum } \\
\text { Mode }\end{array}$ & $\begin{array}{l}\Delta \text { Importance } M \\
\quad \text { R3 to R4 }\end{array}$ \\
\hline $\begin{array}{l}\text { Utilize feedback and advice to } \\
\text { advance one's range of career } \\
\text { opportunities }\end{array}$ & 3.75 & 0.75 & 0.20 & 1.00 & 2.06 & 2.0 & 2 & 0.00 \\
\hline $\begin{array}{l}\text { Calculate the consequences of } \\
\text { irrational long-term and career- } \\
\text { limiting decisions }\end{array}$ & 3.69 & 0.77 & 0.21 & 1.00 & 2.25 & 2.0 & 2 & 0.00 \\
\hline $\begin{array}{l}\text { Advocate for oneself with respect to } \\
\text { ones' career (ex. calling to schedule } \\
\text { an interview) }\end{array}$ & 3.69 & 0.77 & 0.21 & 1.00 & 2.25 & 2.0 & 2 & 0.00 \\
\hline $\begin{array}{l}\text { Acknowledge expertise/experience as } \\
\text { beneficial qualities to seek in career } \\
\text { advisors }\end{array}$ & 3.69 & 0.98 & 0.27 & 1.00 & 1.88 & 2.0 & 2 & 0.00 \\
\hline $\begin{array}{l}\text { Indicate how different skill sets and } \\
\text { predispositions relate to different } \\
\text { career fields }\end{array}$ & 3.69 & 0.77 & 0.21 & 1.00 & 1.75 & 2.0 & 2 & 0.00 \\
\hline $\begin{array}{l}\text { Take the initiative to seek out career } \\
\text { information and discuss it }\end{array}$ & 3.69 & 0.58 & 0.16 & 1.00 & 1.88 & 2.0 & 2 & 0.06 \\
\hline $\begin{array}{l}\text { Contact, obtain permission, and } \\
\text { prepare a list of professional } \\
\text { references appropriate for a specific } \\
\text { job opportunity }\end{array}$ & 3.63 & 0.60 & 0.17 & 1.00 & 2.31 & 2.0 & 2 & 0.00 \\
\hline $\begin{array}{l}\text { Analyze an environment to address } \\
\text { barriers to career entry }\end{array}$ & 3.56 & 0.70 & 0.20 & 1.00 & 2.13 & 2.0 & 2 & 0.00 \\
\hline $\begin{array}{l}\text { Knowledge of one's own past } \\
\text { triggers, as a precursor to managing } \\
\text { professional demeanor in a given } \\
\text { environment }\end{array}$ & 3.56 & 0.93 & 0.26 & 1.00 & 2.25 & 2.0 & 3 & 0.00 \\
\hline $\begin{array}{l}\text { Communicate with experienced } \\
\text { people with respect to a given career } \\
\text { field }\end{array}$ & 3.56 & 0.61 & 0.17 & 1.00 & 1.94 & 2.0 & 2 & 0.00 \\
\hline $\begin{array}{l}\text { Translate career progressions and } \\
\text { different steps within a career ladder }\end{array}$ & 3.50 & 0.61 & 0.17 & 1.00 & 2.44 & 2.0 & 2 & 0.00 \\
\hline
\end{tabular}

\section{Discussion}

The first research objective was to determine the concepts and skills that define career literary. After four rounds, the panelists determined that career literacy is the embodiment of 50 skills. The largest change in importance from Round 3 to Round 4 was -.25 , which according to Rowe and Wright (2011), is typical of a largely homogenous expert panel. Defining and measuring career literacy will help educators determine a student's current career literacy status. Further, the results can provide guidance around potential strategies and skills students need to increase career literacy and become more proficient at preparing for their lives after high school. The results of a measure like this may provide educators and other stakeholders with students' scaffolding needs and interdisciplinary connections that will be entry experiences with these skills within all of their coursework.

To address the second objective of this research was to create an acquisition continuum of career literacy skills. At the conclusion of Round 4, the continuum was created by reaggregating the concepts and skills into functional, interactive, and critical skills that represent the type of interaction students need to develop with the concepts. 
An ordinal continuum of these skills can improve their successful integration into academic curricula in a more authentic and meaningful way. This list of concepts and skills can be used in the development in transition plans for students with Individualized Education Plans (IEP). Along the same lines, educators and parents can provide students with experiences to construct their personal understanding and development of the career literacy skills if they are broken down into actionable learning outcomes.

Most Important Skills. The most important idea agreed upon by the panelists, "decipher information presented in different forms (orally, written, visually, etc.)" aligns with the more traditional, previously held descriptions of academic literacy (Heathington, 1987). Of the top five important concepts and skills, four are functional. These skills represent what industry considers to be the most important for successful transition into employment. Their place on the list is not surprising considering the nature of the panelists' experiences and current positions. The five skills and concepts with the highest means involve different opportunities to strengthen reading and comprehension, teamwork, and communication skills.

Developing Self-Efficacy. Lent and Brown (2013) refer to self-efficacy as the way an individual perceives their ability to perform career preparation tasks. All of the skills that involve self-awareness and reflection are interactive or critical. Development of these specific skills through the career lens requires students, at a minimum, to have a functional understanding of careers. Maturity for engaging in this level of self-reflection, according to Super (1953), is also feasible for adolescents. The first concept or skill involving personal awareness appears as the $9^{\text {th }}$ important skill; however, much of the focus of career development focuses on interests and efficacy. This suggests career literacy as a tandem evaluation rather than a replacement measure.

Complicated Skill Development. Of the six skills with the highest SD, indicating a greater dispersion of perceptions, five may be the most difficult to teach, measure, and for students to acquire. The following skills, excepting manipulating math skills, may be complicated to assess through a quantitative psychometric measure:

- Ask the "right" questions to seek answers, provide clarity, or to problem-solve $S D=$ $1.07, C V=0.28$

- Use one's own discernment, empathy, and grit in communication and goal setting $S D$ $=1.05, C V=0.26$

- Knowledge of appropriate vernacular by audience (code-switching) $S D=1.05, C V=$ 0.26

- Acknowledge expertise/experience as beneficial qualities to seek in career advisors, $S D=0.98, S D=0.27$

- Manipulate basic math functions, exemplifying data literacy, $S D=0.95, C V=0.25$

- Knowledge of one's own past triggers, as a precursor to managing professional demeanor in a given environment, $S D=0.93, S D=0.26$

These skills and concepts are subjective because mastery may be assessed differently based on the reviewer's ability in each area. Additionally, this skill evaluation could be filtered through a lens that emphasizes norms accepted by a dominant culture over other cultures. Both instances may disadvantage students' development with these concepts and skills.

Practical Applications. The data suggest the necessity for developing the ability to meaningfully interact with career-related information. Perkins IV incorporated the need for 
career skills to be infused into all curricular areas (Carl D. Perkins Career and Technical Education Improvement Act, 2006). Perkins V requires the development of employability skills (Strengthening Career and Technical Education for the $21^{\text {st }}$ Century Act, 2018). The continued focus on improving career skills for students indicates that more, or different, work needs to be done at the school level to help students position themselves to meaningfully participate in the workforce.

In order to make it practical and manageable for teachers to incorporate career literacy skills into their instruction, it might be important to develop categorical representations. The researchers offer the following categories of career literacy skills: career research, effective communication, information understanding, analysis, and application, personal disposition, selfawareness and observation, and teamwork. These categories are similar to an analysis of definitions for college and career readiness by state education boards across the United States with defined expectations (Mishkind, 2014). The six categories established in the report are: academic knowledge, critical thinking and/or problem-solving, social-emotional learning, grit (resilience and perseverance), citizenship, and other. Critical thinking and problem-solving, along with social emotional learning and grit, resilience, and perseverance, are solidly represented as a result of this study. Academic knowledge, citizenship, and the "other" category are represented collectively in two skills. Other categorizations have been offered through career readiness studies, developed career assessments, and industry. The specific categorizations should be developed through additional research and consider prominent work that may offer a logical progression from career literacy to career readiness so that teachers can integrate these concepts and skills with ease.

Some concepts and skills appear on the list in more than one category, likely as a result of keeping the lists disaggregated throughout the process. It also provides an indication of the progressive nature of the skills' development since it could have been listed in each category demonstrating the need for students to interact with the concept or skill in more than one way. The examples that follow illustrate a continuum of higher order skills necessary for its effective application.

Example 1:

The functional skill "decipher information presented in different forms (orally, written, visually, etc.)" indicates the basic knowledge and skills required before going forward. After a student can decipher information, they can begin to more effectively engage with the interactive skill, "read, process, and interpret career information regarding employment". After a student becomes more proficient with interpreting career information regarding employment, they are positioned more effectively to enact the critical skill of "relating one's own academic/skill portfolio with desirable career paths."

Example 2:

Using the same functional element, decipher information presented in different forms, a student may be able to more effectively engage with the interactive concept and "indicate how different skill sets and predispositions relate to different career fields" and subsequently the critical concept of "identifying basic requirements of a job to determine whether one meets said requirements".

The 10 skills with the lowest means on the list almost exclusively represent job acquisition or work-place skills. The list of skills and concepts that fall toward the bottom of the 
Journal of Research in Technical Careers

list are largely geared toward skills that need to be developed later along the continuum of skills and may reflect skills that need to be explicitly taught rather than acquired through experience alone.

\section{Limitations}

The Delphi panelists were asked to broadly indicate school levels for each skill. In order to best facilitate the integration of career literacy concepts and skills into the curriculum, the continuum would need to have more defined entry points like specific ages or grade-levels. None of the invited participants from the north region of the United States participated. Shortly after the commencement of this study, a global pandemic was declared which meant that many of the experts, as they were largely decision-makers in their respective educational setting, had to shift their focus to unusually demanding work considerations. The time between rounds was significant and may have been a factor of the attrition rate in the study.

\section{Recommendations and Future Work}

Prior to the commencement of this study, the researchers were expecting more granular responses to the questions. In response to functional, interactive, and critical career literacy, it was expected that specific vocabulary would be included, in addition to the specific types of experiences required, as the actual literacy element. An additional study should be undertaken to determine, more specifically, a task analysis of the concepts and skills that need to be taught in order to more closely align entry points of this work, and to improve students' movement along the continuum. Additionally, because students develop these traits over several years and from various entities, further research should be conducted to determine the stakeholders most influential and responsible for a student's development along the career literacy continuum.

These findings support the idea that there are many career concepts and skills that middle school students need to begin developing which could also be an effective drop-out prevention strategy, especially if curriculum developers emphasize personal career connections early (Godbey \& Gordon, 2019). Infusing career literacy development activities into secondary curriculum may increase these essential career connections and create additional touchpoints for conversation. Career literacy skills can then be more closely aligned to increase interdisciplinary integration into the curriculum to increase skill preparation and experience in middle school.

The overarching goal of the college and career skills lean heavily toward academic achievement and knowledge of and specific preparation for one's postsecondary or career plans. The concepts and skills identified as necessary to facilitate students' career literacy can be explicitly incorporated into career pathway studies, in addition to other interdisciplinary curricula, to ensure intentional engagement with these concepts, supporting the Perkins V edict of including academic knowledge and employability skills into the curriculum (Strengthening Career and Technical Education for the $21^{\text {st }}$ Century Act, 2018).

Career decision making problems exist among secondary students with primary causes identified as lack of efficacy, indecision, and lack of information (Kulcsar et al., 2020). Developing career literacy skills along the continuum may provide students a skill set to combat many of these decision-making issues.

The categories offered by Mishkind (2014) could be used to group the list of skills and concepts provided as the embodiment of career literacy, as they closely align with the categories 
determined by the researchers. Going forward, it may be helpful to adopt the same categories used to describe career readiness as an examination of career literacy to maintain consistency for curriculum development and measurement of students' progress over time as recommended by Malin et al. (2017). It will be critical to involve community organizations and businesses in the development of students' career literacy. Developing many of these skills will involve creating opportunities for students to observe and participate first-hand. Work-based learning and student internships fit this need.

The skills that make up career literacy represent many of the same skills indicated as necessary for college and career readiness. The findings from this study, or the concepts and skills and the continuum of career literacy skills, offer a breakdown and progression of learning as students constantly develop and improve from career literacy acquisition to career readiness. Therefore, an additional study determining the stakeholders responsible for developing a student's career literacy skills might help establish the work at the implementation level and increase the integration of these skills into classroom instruction.

\section{Summary}

Career literacy represents a student's ability to read, interpret, and make decisions based on career-related information. This four-round Delphi study provided subject matter experts the opportunity to name and quantify 50 specific skills that a student needs to be proficient in career literacy and the appropriate school level for initial exposure to those skills. Using similar language to connect the preparatory skills required for the development of career literacy, as a precursor to career readiness, will offer educators and other stakeholders a valuable data set about a student's progression and preparation for their postsecondary success. With this information, educators, parents, and other influential individuals can provide targeted intervention and experiences to promote development along the career literacy continuum.

\section{References}

ERIC. (March 2013). How career and technical education can help students be college and career ready: A primer. College and Career Readiness and Success Center. https://ccrscenter.org/productsresources/how-career-and-technical-education-can-help-students-be-college-and-career-ready

Bennett, D., \& Robertson, R. (2015). Preparing students for diverse careers: Developing career literacy with final-year writing students. Journal of University Teaching and Learning Practice, 12(3), 5. http://ro.uow.edu.au/jutlp/vol12/iss3/5

Bonett, R. M. (1994). Marital status and sex: Impact on career self-efficacy. Journal of Counseling \& Development, 73(2), 187-190. https://doi.org/10.1002/j.1556-6676.1994.tb01734.x

Brumwell, S., Deller, F., \& MacFarlane, A. (2017). Why measurement matters: The learning outcomes approach-A case study from Canada. Journal of Higher Education in Africa/Revue de l'enseignement supérieur en Afrique, 15(1), 5-22. https://codesria.org/IMG/pdf/1_why_measurement_matters-.pdf

Cameron, L., Wise, S. L., \& Lottridge, S. M. (2007). The development and validation of the information literacy test. College \& Research Libraries, 68(3), 229-237. https://doi.org/10.5860/crl.68.3.229

Carl D. Perkins Career and Technical Education Improvement Act of 2006, 20 U.S.C. $\S 2301$ et seq. (2006). https://www.congress.gov/109/plaws/publ270/PLAW-109publ270.pdf

Childress, V., \& Rhodes, C. (2006). Engineering student outcomes for grades 9-12. Research in engineering and technology education. National Center for Engineering and Technology Education. https://files.eric.ed.gov/fulltext/ED538908.pdf 
Journal of Research in Technical Careers

Choi, Y., Kim, J., \& Kim, S. (2015). Career development and school success in adolescents: The role of career interventions. Career Development Quarterly, 63(2), 171-186. https://doi.org/10.1002/cdq.12012

College and Career Readiness, VA. Stat. § 8VAC20-131-140 (2019). https://law.lis.virginia.gov/admincode/title8/agency20/chapter131/section140/

Cook, K. C. (2002). Layered literacies: A theoretical frame for technical communication pedagogy. Technical Communication Quarterly, 11(1), 5-29. https://doi.org/10.1207/s15427625tcq1101_1

Doustmohammadian, A., Omidvar, N., Keshavarz-Mohammadi, N., Abdollahi, M., Amini, M., \& EiniZinab, H. (2017). Developing and validating a scale to measure food and nutrition literacy (FNLIT) in elementary school children in Iran. PLOS ONE, 12(6), Article e0179196. https://doi.org/10.1371/journal.pone.0179196

English, J. M., \& Kernan, G. L. (1976). The prediction of air travel and aircraft technology to the year 2000 using the Delphi method. Transportation research, 10(1), 1-8. https://doi.org/10.1016/00411647(76)90094-0

Geist, M. R. (2010). Using the Delphi method to engage stakeholders: A comparison of two studies. Evaluation and Program Planning, 33(2), 147-154. https://doi.org/10.1016/j.evalprogplan.2009.06.006

Gibbons, M. M., \& Shoffner, M. F. (2004). Prospective first-generation college students: Meeting their needs through social cognitive career theory. Professional School Counseling, 8(1). 91-97. http://www.jstor.org/stable/42732419

Gill, F. J., Leslie, G. D., Grech, C., \& Latour, J. M. (2013). Using a web-based survey tool to undertake a Delphi study: Application for nurse education research. Nurse Education Today, 33(11), 13221328. https://doi.org/10.1016/j.nedt.2013.02.016

Godbey, S., \& Gordon, H. R. (2019). Career exploration at the middle school level: Barriers and opportunities. Middle Grades Review, 5(2). https://scholarworks.uvm.edu/mgreview/vol5/iss2/2

Gottfredson, L. S. (2005). Using Gottfredson's theory of circumscription and compromise in career guidance and counseling. Career Development and Counseling: Putting Theory and Research to Work, 71-100.

Guillon, V., Dosnon, O., Esteve, M. D., \& Gosling, P. (2004). Self-efficacy and behavioral intention: A mediational analysis of the effects of commitment on career counseling. European Journal of Psychology of Education, 19(3), 315. https://doi.org/10.1007/BF03173226

Habibi, A., Sarafrazi, A., \& Izadyar, S. (2014). Delphi technique theoretical framework in qualitative research. The International Journal of Engineering and Science, 3(4), 8-13. http://www.theijes.com/papers/v3-i4/Version-4/B03404008013.pdf

Heathington, B. S. (1987). Expanding the definition of literacy for adult remedial readers. Journal of Reading, 31(3), 213-217.

Holloway, K. (2012). Doing the E-Delphi: using online survey tools. CIN: Computers, Informatics, Nursing, 30(7), 347-350. https://doi.org/10.1097/NXN.0b013e31825e8923

Hsu, C. C., \& Sandford, B. A. (2007). Minimizing non-response in the Delphi process: How to respond to non-response. Practical Assessment, Research \& Evaluation, 12(17), 62-78. https://doi.org/10.7275/by88-4025

Julien, H. E. (1999). Barriers to adolescents' information seeking for career decision making. Journal of the American Society for Information Science, 50(1), 38-48.

Kay, J. S., Shane, J., \& Heckhausen, J. (2017). Youth's causal beliefs about success: socioeconomic differences and prediction of early career development. Journal of Youth and Adolescence, 46(10), 2169-2180. https://doi.org/10.1007/s10964-017-0708-2

Kezar, A., \& Maxey, D. (2016). The Delphi technique: An untapped approach of participatory research. International Journal of Social Research Methodology, 19(2), 143-160. https://doi.org/10.1080/13645579.2014.936737 
Kulcsár, V., Dobrean, A., \& Gati, I. (2020). Challenges and difficulties in career decision making: Their causes, and their effects on the process and the decision. Journal of Vocational Behavior, 116, Article 103346. https://doi.org/10.1016/j.jvb.2019.103346

Lapan, R. T., Poynton, T., Marcotte, A., Marland, J., \& Milam, C. M. (2017). College and Career Readiness Counseling Support Scales. Journal of Counseling \& Development, 95(1), 77-86. http://doi.org/10.1002/jcad.12119

Larsen, K. (2007). Health literacy. In W. Stauffer, P. Walker, E. Barnett, \& J. Jaranson (Eds.,) Immigrant medicine (pp. 711-724). WB Saunders.

Lau, W. W., \& Yuen, A. H. (2014). Developing and validating of a perceived ICT literacy scale for junior secondary school students: Pedagogical and educational contributions. Computers \& Education, 78, 1-9. https://doi.org/10.1016/j.compedu.2014.04.016

Leland, C. H., Harste, J. C., \& Shockley, C. J. (2007). Literacy education, equity, and attitude. Language Arts, 85(2), 134-143. http://www.jstor.org/stable/41962255

Lent, R. W., \& Brown, S. D. (2013). Social cognitive model of career self-management: Toward a unifying view of adaptive career behavior across the lifespan. Journal of Counseling Psychology, 60, 557-568. https://doi.org/10.1037/a0033446

Lent, R. W., Brown, S. D., \& Hackett, G. (1994). Toward a unifying social cognitive theory of career and academic interest, choice, and performance. Journal of Vocational Behavior, 45(1), 79-122. https://doi.org/10.1006/jvbe.1994.1027

Lent, R. W., Ireland, G. W., Penn, L. T., Morris, T. R., \& Sappington, R. (2017). Sources of self-efficacy and outcome expectations for career exploration and decision-making: A test of the social cognitive model of career self-management. Journal of Vocational Behavior, 99, 107-117. https://doi.org/10.1016/j.jvb.2017.01.002

Liu, Y., Mao, Y., \& Wong, C. S. (2020). Theorizing parental intervention and young adults' career development: A social influence perspective. Career Development International, 25(4), 415-428. https://doi.org/10.1108/CDI-01-2019-0028

Malin, J. R., Bragg, D. D., \& Hackmann, D. G. (2017). College and career readiness and the Every Student Succeeds Act. Educational Administration Quarterly, 53(5), 809-838. https://doi.org/10.1177/2F0013161X17714845

Martin, G., \& Ritz, J. (2012). Research needs for technology education: A US perspective. Journal of Technology Education, 23(2), 25-43. https://digitalcommons.odu.edu/cgi/viewcontent.cgi?article=1034\&context=stemps_fac_pubs

McFadden, A., \& Curry, J. R. (2018). State leaders' and school counselors' roles in elementary and middle school career development: Research findings and promising practices. Techniques: Connecting Education \& Careers, 93(3), 46-49.

Meijering, J. V., Kampen, J. K., \& Tobi, H. (2013). Quantifying the development of agreement among experts in Delphi studies. Technological Forecasting and Social Change, 80(8), 1607-1614. https://doi.org/10.1016/j.techfore.2013.01.003

Mishkind, A. (2014). Overview: State definitions of college and career readiness. College and Career Readiness and Success Center. American Institutes for Research. https://eric.ed.gov/?id=ED555670

Okoli, C., \& Pawlowski, S. D. (2004). The Delphi method as a research tool: An example, design considerations and applications. Information \& Management, 42(1), 15-29. https://doi.org/10.1016/j.im.2003.11.002

Paré, G., Cameron, A. F., Poba-Nzaou, P., \& Templier, M. (2013). A systematic assessment of rigor in information systems ranking-type Delphi studies. Information \& Management, 50(5), 207-217. https://doi.org/10.1016/j.im.2013.03.003

Preble, J. F. (1984). The selection of Delphi panels for strategic planning purposes. Strategic Management Journal, 5(2), 157-170. https://doi.org/10.1002/smj.4250050206 
Rowe, G., \& Wright, G. (2011). The Delphi technique: Past, present, and future prospects - Introduction to the special issue. Technological Forecasting and Social Change, 78(9), 1487-1490. https://doi.org/10.1016/j.techfore.2011.09.002

Street, B. (2003). What's "new" in new literacy studies? Critical approaches to literacy in theory and practice. Current Issues in Comparative Education, 5(2), 77-91. https://www.tc.columbia.edu/cice/pdf/25734_5_2_street.pdf

Strengthening Career and Technical Education for the $21^{\text {st }}$ Century Act, P. L. $115-24 \S 132$ Stat (2018). https://uscode.house.gov/statutes/pl/115/224.pdf

Super, D. E. (1953). A theory of vocational development. American Psychologist, 8(5), 185-190. https://doi.org/10.1037/h0056046

Symonds, W. C., Schwartz, R., \& Ferguson, R. F. (2011). Pathways to prosperity: Meeting the challenge of preparing young Americans for the 21st century. Pathways to Prosperity Project, Harvard University Graduate School of Education. http://nrs.harvard.edu/urn-3:HUL.InstRepos:4740480

Tang, M., Pan, W., \& Newmeyer, M. (2008). Factors influencing high school students' career aspirations. Professional School Counseling, 11(5), 285-295. https://psycnet.apa.org/doi/10.5330/PSC.n.2010-11.285

Turner, S. L., Joeng, J. R., Sims, M. D., Dade, S. N., \& Reid, M. F. (2019). SES, gender, and STEM career interests, goals, and actions: A test of SCCT. Journal of Career Assessment, 27(1), 134150. https://doi.org/10.1177/1069072717748665

Vidgen, H. A., \& Gallegos, D. (2014). Defining food literacy and its components. Appetite, 76, 50-59. https://doi.org/10.1016/j.appet.2014.01.010

Vogel, C., Zwolinsky, S., Griffiths, C. et al. A Delphi study to build consensus on the definition and use of big data in obesity research. International Journal of Obesity, 43, 2573-2586 (2019). https://doi.org/10.1038/s41366-018-0313-9

Wester, K. L., \& Borders, L. D. (2014). Research competencies in counseling: A Delphi study. Journal of Counseling \& Development, 92(4), 447-458. https://doi.org/10.1002/j.1556-6676.2014.00171.x

Williams, O., Quinn, E. L. H., Ramirez, M., Sawyer, V., Eimicke, J. P., \& Teresi, J. A. (2017). Development of a menu board literacy and self-efficacy scale for children. Journal of Nutrition Education and Behavior, 49(10), 867-871. https://doi.org/10.1016/j.jneb.2017.07.008 